exceptionally difficult to do blinded studies in our patients because the owners or trainers specifically seek an institution for stem-cell therapy," says Lisa Fortier, a veterinary surgeon at Cornell University in Ithaca, New York, and a co-author of the 2010 cartilage study.

Without controlled trials, comparisons between treated and untreated animals are difficult. Owners who have paid a few thousand dollars for a therapy are more likely to follow strict rehabilitation protocols than those who have not. They are also more likely to rush horses back into action, which would skew reported recovery time, a measure of a treatment's effectiveness. And placebo effects - on the owners can be powerful. "The cat looks like hell to me but the owner says: 'She looks so great. I love stem cells'” says Borjesson.

Many veterinarians think that studying stem-cell therapies in large animals, which are more physiologically similar to humans than the mice often used in preclinical research, could be a powerful model for medicine - if studies are done right. Borjesson is running studies (with "as much blinding as possible") of stem-cell treatments for dry eye, another eye condition called recurrent uveitis, and inflammatory bowel disease in clients' pet dogs. She is also collaborating with researchers in human regenerative medicine, so that her findings can inform their studies of experimental therapies. And David Frisbie, a veterinary surgeon at Colorado State University in Fort Collins, is working with doctors to apply lessons from animal stem-cell treatments to joint injuries in humans.

If the pending FDA guidance clearly designates animal stem cells as drugs, veterinarians and companies who want to deploy such treatments will first have to conduct clinical trials, which Frisbie estimates could cost at least US $\$ 5$ million each. Nobert, meanwhile, is optimistic that veterinary stem-cell companies and university researchers will find ways to "design creative regulatory approval strategies to streamline and expedite the review-andapproval process" - which might, in turn, influence the human stem-cell regulatory process.

Still, he worries that overly stringent FDA rules about, for example, how cells are characterized, could "make the ultimate commercial price unreasonable".

For Vinty, it's a moot point. He's had his stem cells. But even with his tendon fixed, he was too slow to race. He now gives riding lessons to children.

1. Black, L. L. et al. Vet. Ther. 8, 272-284 (2007).

2. Fortier, L. A. et al. J. Bone Joint. Surg. Am. 18, 1927-1937 (2010).

3. Godwin, E. E., Young, N. J., Dudhia, J., Beamish, I. C. \& Smith, R. K. W. Equine Vet. J. 44, 25-32 (2012).

\title{
Budget forces tough look at biodefence
}

\section{US supply stockpile for combating bioterror attacks and pandemics feels the strain of funding cuts.}

\section{BY ERIKA CHECK HAYDEN}

B udget cuts mean painful choices for managers of the US Strategic National Stockpile, a medical repository initially designed to aid the country's response to terrorist attacks.

Congress created a national stockpile in 1998, and this has grown into an all-purpose resource that can deliver supplies to a disaster site within 12 hours. But the federal budget crisis has reduced the stockpile's funding by $18 \%$ over the past four years (see 'Running Low'), raising doubts about whether the United States can afford to be prepared for every pandemic or natural disaster, from bird flu to hurricanes.

At a 3 April meeting, advisers to the Department of Health and Human Services (DHHS) unanimously endorsed a report recommending that the stockpile rely on science to guide decisions about what threats are most likely, what supplies are needed to respond and whether local officials can actually use them. "The [stockpile] will be buying less. There's no doubt about it," said Ali Khan, who directs the public health and preparedness office at the US Centers for Disease Control and Prevention in Atlanta, Georgia, which oversees the stockpile.

Federal officials are struggling to weigh up competing priorities. State and local disaster-response agencies increasingly rely on the stockpile to compensate for cuts to their own budgets. But the national programme is also the only buyer for expensive, specialized treatments developed after the 2001 World

\section{RUNNING LOW}

Strong financial support for the Strategic National Stockpile has given way to harsh budget reality.

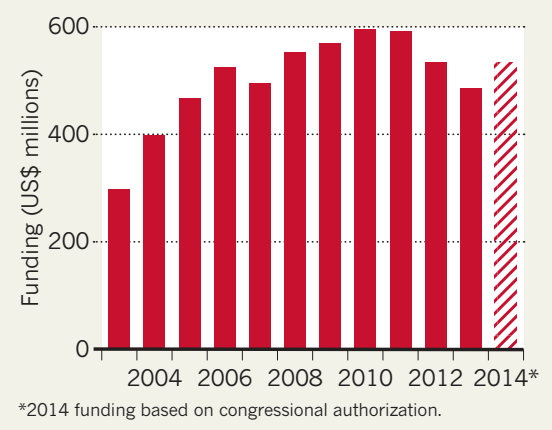

Trade Center and anthrax terrorist attacks. It is spending increasing amounts on therapies that are unlikely ever to be used.

"There has clearly been mission creep," said Steve Krug, director of emergency medicine at the Ann \& Robert H. Lurie Children's Hospital of Chicago in Illinois at the 3 April meeting.

The DHHS has already sharply reduced orders for some items, including a new botulism antitoxin that costs US $\$ 1,250$ per dose. Such decisions alarm companies making biodefence products, says Maureen Hardwick, executive secretary of the Alliance for Biosecurity in Washington DC, which represents many of those firms. "If they're researching and developing things that will not be procured, that sends a negative signal," Hardwick says.

But just replacing expired medications already in the stockpile will exceed the repository's projected budget by $20 \%$ next year. And the programme will eventually be asked to restock other high-priced anti-bioterrorism drugs first purchased by a separate agency, the Biomedical Advanced Research and Development Authority (BARDA), which supports the development of medications considered priorities for biosecurity.

BARDA has purchased 2 million doses of an anti-smallpox drug for more than $\$ 150$ per dose, even though the stockpile already contains enough smallpox vaccine to immunize the entire US population.

The stockpile will also foot the bill for two biological products to neutralize the toxin produced by anthrax bacteria, first purchased by BARDA at costs of $\$ 2,900-3,500$ and $\$ 8,100$ per dose. Meanwhile, the country continues to invest in biodefence research.

Fewer purchases may mean that the United States will be less prepared for unlikely events, such as bioterrorist attacks, than officials would like. But other nations made this trade-off long ago. Only two other countries - Japan and Israel - are thought to have enough smallpox vaccine to vaccinate their entire populations. And no other country has anything like the anti-bioterrorism arsenal of the United States.

"There has to be a thoughtful analysis of what we're willing to do without, which is a very painful discussion in our society," Krug said at the meeting. 